\title{
Stimulated decomposition in peat for engineering applications
}

1 Som P. Pichan PEng, MBEM

MSc Candidate, Department of Civil, Structural and Environmental Engineering, Trinity College Dublin, Dublin, Ireland
2. Brendan C. O'Kelly MEngSC, PhD, FTCD, CEng, CEnv, MICE, FIEl

Associate Professor, Department of Civil, Structural and Environmental Engineering, Trinity College Dublin, Dublin, Ireland
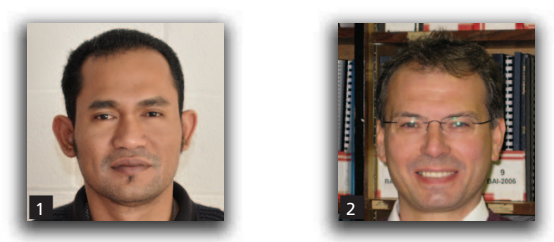

Peat deposits are highly compressible, undergoing significant long-term settlement, particularly for fibrous peat. Since decomposition of organic matter can have a significant effect on compression behaviour, the ability to artificially stimulate and pre-decompose a bearing peat stratum prior to the main construction works may mitigate against increased compression rates reported to occur over the design life. This paper presents a feasibility trial of a technique that accelerates the decomposition process in peat prior to entering into full laboratory and field testing. The main decomposition limiting factors of $\mathrm{pH}$ and carbon:nitrogen (C:N) ratio are adjusted by adding sufficient amounts of basic and nitrogenous materials. The proposed technique can be tailored for specific peat deposits and can also be achieved in a more sustainable manner. In the trial on moderately decomposed fibrous Sphagnum peat, different peat blends were prepared using additives of peat pulverised fuel ash (PPFA) and urea. Optimum C:N ratio and $\mathrm{pH}$ for decomposition were achieved by adding $\sim 21 \mathrm{~kg}$ PPFA and $\sim \mathbf{1 . 5} \mathrm{kg}$ urea per cubic metre of wet peat. The availability of natural decomposers in the peat was also confirmed pre- and post-treatment using a plate count technique, with measured microorganism populations of the order of $10^{5}$ colony-forming units (CFU)/g dry peat.

\section{Introduction}

Peat deposits (mire) are formed by the gradual accumulation of the remains of dead vegetation in various stages of decomposition, and this accumulation can build up where there is a reservoir of water to promote growth and to preserve the remains (Farrell, 2012). In situ peat has an extremely high water content, ranging from a few hundred per cent of dry mass to greater than $2000 \%$ (Hobbs, 1986), which results in characteristic low strength and high compressibility (O'Kelly, 2006a; Mesri and Ajlouni, 2007). Decomposition or biological oxidation in peat produces a permanent material change whereby large fibres and plant cellular structures are broken down, adsorption complexes on the cell walls are weakened (Wardwell et al., 1983), pore space decreases in size and the proportion of fine material increases (Blackford and Chambers, 1993), ultimately producing an amorphous granular material. However, the decomposition rate is generally extremely slow under normal subsurface conditions on account of the non-conducive environment of natural ecosystems.

Some researchers have suggested that certain creep deformations observed in peats may be related more to biological activity than to mechanical stress (Wardwell et al., 1983). The compressibility is influenced by decomposition in two ways: $(a)$ a reduction in dry solids mass (volume) associated with the microbial metabolism; $(b)$ increased compressibility of the organic matter as the organic structure loses its integrity.

Decomposition or biological oxidation in mire mainly occurs on account of intermittent fluctuations of the groundwater table, either produced naturally or by anthropogenic activity (e.g. constructed drainage schemes). Groundwater fluctuations cause air ingress, increasing the oxygen concentration in soil by as much as four orders of magnitude (Matthiesen, 2004), with these more favourable conditions increasing the decomposition rate. This is in line with recent developments in microbiology that indicate that biological activity can develop naturally or may be promoted by altering limiting factors - for example, by injecting nutrients such as glucose and oxygen or changing the environmental conditions (Mitchell and Santamarina, 2005). Recent studies by the authors (Pichan and O'Kelly, 2012) also indicated that the rate of decomposition for fibrous peat can be accelerated by altering the carbon:nitrogen $(\mathrm{C}: \mathrm{N})$ ratio, $\mathrm{pH}$, oxygen supply and temperature for optimum conditions.

Since the decomposition rate is generally extremely slow under anoxic conditions, the general consensus in geotechnical literature 
has been that decomposition does not have a significant impact on performance over the design life of pertinent engineering works. Hence, the effect of active decomposition on the engineering properties and behaviour of peat has not been investigated sufficiently. Decomposition may be accelerated remarkably once the natural equilibrium of the peat ecosystem has been altered. For example, Mesri and Ajlouni (2007) reported that the decomposition rate increases for peat sampled out of the ground due to the increase in oxygen supply, contact with water of higher $\mathrm{pH}$ and higher ambient temperature.

Agricultural, botanical and environmental disciplines have recognised the potentially significant effects of decomposition, which have been reported in some instances as the dominant factor controlling secondary compression settlement in mire (Drexler et al., 2009). Secondary settlement in peat is substantial, often exceeding primary consolidation (hydrodynamic) settlement (Farrell, 2012), with significant implications for land use, planning and development. Numerous case studies concerning mire have been reported in which the bulk of the subsidence was attributed to the decomposition of organics. For example, $55-80 \%$ subsidence of the Sacramento-San Joaquin Delta peat deposit, California, USA, was mainly caused by decomposition (Drexler et al., 2009). Beuving and van den Akker (1996) reported that in grassland on peat, almost $0.5 \mathrm{~m}$ thickness of peat is oxidised per 100 years. A similar subsidence rate (i.e. $>150 \mathrm{~mm}$ over a 35 -year monitoring period) reported for ombrotrophic parts of the Komosse Bog Complex, Sweden, was attributed to decomposition that occurred on account of changes in climate, hydrology and rate of nutrient supply (Franzen, 2006). For constructed peat dykes (levees), with a somewhat thicker aerated zone, the mass of peat disappearing in the atmosphere will be somewhat higher than these rates.

The research presented in this paper is part of a broader study by the authors on the effects of decomposition on the compressibility of peat. The level of decomposition can provide an indication of the likely geotechnical properties, with more decomposed peats generally less compressible and also less prone to further consolidation (Price et al., 2005). The structural rearrangement of the peat fibres and the manner in which pore water is held and expelled between micro- and macro-pores (O'Kelly, 2013) has been linked to high secondary compression in peat (Hobbs, 1986; Mesri and Ajlouni, 2007). Hence, the premise of this research is that the destruction of the open cellular structure of the peat fibres, transformation of organic matter into humic substances, and conversion into gases at the final stage of the decomposition process is of significant importance to the compression behaviour of peats. From a geotechnical engineering perspective, the uncontrolled or unexpected decomposition of in situ peat can potentially pose a risk to the long-term performance of engineering works, considering that decomposition can cause significant changes in geotechnical properties over time (Landva et al., 1983). For instance, in the earlier peat dyke example, the crest of a dyke constructed about 200 years ago will have been lowered by about $1.0 \mathrm{~m}$ on account of ongoing decomposition/oxidation which continues at the present day. This example requires careful attention, since not only the height of the dyke must be considered regarding overtopping but also conditions affecting its geotechnical stability. By contrast, a properly engineered adjustment of the limiting factors in order to accelerate the decomposition of organics in peat prior to the start of the main construction works could positively alter the compression behaviour of the bearing peat stratum over the design life.

The present study has two main themes. First, a literature review is presented on the decomposition limiting factors for peats. Second, an experimental laboratory study designed to create the optimum conditions for decomposition in fibrous peat is reported. The aim of the latter was to investigate the feasibility of a pretreatment technique that could be tailored for a specific peat deposit and achieved in a sustainable manner. In particular, peat pulverised fuel ash (PPFA), which is a by-product of the combustion of pulverised peat at electricity-generating power plants, was investigated as a suitable additive. The disposal of this ash is an ever-increasing problem for major PPFA-producing countries such as Ireland and Finland. This technique could be applicable for any type of fibrous peat, and also extended to other degradable organic materials, provided the decomposition-limiting factors can be modified for optimum conditions.

\section{Limiting factors for decomposition of peat}

Mires naturally occur in waterlogged conditions. Water is crucial for the survival of microorganisms since water supports nutrient transport, participates in chemical reactions, determines the type and concentration of soluble materials (including salts and minerals), establishes the environment's $\mathrm{pH}$, controls aeration and contributes to thermal stability (Mitchell and Santamarina, 2005). Decomposition in peat is driven by consortia of microorganisms, including bacteria and fungi (Hobbs, 1986; Pankratov et al., 2011), which require carbon for metabolic processes that form cell components and produce energy in order to sustain life. The optimum condition for aerobic microbia activity requires a degree of saturation of $60-80 \%$ (Mitchell and Santamarina, 2005). However, prolonged immersion under highly saturated conditions causes a reduction in oxygen supply, progressively leading to more anaerobic conditions, and hence slower microbial activity (Hobbs, 1986).

Optimum growth of bacteria in soil is also restricted by lack of nutrients, particularly nitrogen and phosphorus (Wardwell et al., 1983). The nitrogen content mainly depends on the morphological stage and also the geology and hydrology of the area, which in turn dictate the chemistry and concentration of nutrients in water entering the mire (Hobbs, 1986). The morphological stage can be categorised as rheotrophic (nutrient-rich), transitional (mesotrophic nutrients) or ombrotrophic (nutrient-deficient). The level of available nutrients in soil can be assessed by the proportion of total carbon to nitrogen content, expressed as C:N ratio. Since peat mostly comprises carbon, with only traces of 
nitrogen, the C:N ratio is high, generally in the range $40: 1$ to 50:1. An increase in the proportion of nitrogen results in higher microbial activity (Hobbs, 1986; Pankratov et al., 2011), with the optimum C:N ratio for decomposition reported in the range 15:1 to 30:1 (Wardwell et al., 1983).

Microbial activity in mire is retarded by high acidity. Its impact is apparent when comparing rich fen peat with acid fen peat. The former is alkaline and more likely to be highly decomposed (Hobbs, 1986). The pH level mainly depends on the origin and chemistry of the water supply (Farrell, 2012), on bacterial activity and also on the dominant plant species in mire (Pankratov et al., 2011). Sometimes peat can be acidified by vegetation growth. Species such as Sphagnum mosses are responsible for acidic conditions and also produce phenolic metabolites, which have antimicrobial properties, slowing the decomposition rate even further (Pankratov et al., 2011). The acidity may be reduced by lime-rich water entering the mire (Hobbs, 1986). For a balanced reaction, the decomposition process requires a near-neutral $\mathrm{pH}$ (Wardwell et al., 1983), with decomposers most active over the $\mathrm{pH}$ range $7 \cdot 0-7 \cdot 5$.

Microbial activity is also greatly inhibited by the relatively low temperature in natural ecosystems, with organisms generally requiring higher temperatures for optimum growth. For example, mesophilic organisms, which are considered as anaerobic bacteria, are usually most active over the temperature range $15-45^{\circ} \mathrm{C}$ in soil, with microbial activity increasing by typically two- to threefold for each $10^{\circ} \mathrm{C}$ increase over this range. The optimum temperature for decomposition of organic matter present as cellulose occurs in the range $35-40^{\circ} \mathrm{C}$ (Hobbs, 1986; O'Kelly, 2008). The decomposition process can reach completion in mire that is exposed to a consistent temperature of $20-30^{\circ} \mathrm{C}$ and for $\mathrm{pH}>5$ (Hobbs, 1986).

\section{Availability of microorganisms}

The life of microorganisms in many soil and rock types has been widely studied. However, the microbial population and activity in peat have hardly been explored and are less well understood (Hingley, 1993). Three main classes of microorganisms are readily available in soil, namely, bacteria, archea and eukarya. These can be distinguished from each other by chemical composition or cell structure (Mitchell and Santamarina, 2005). In optimum environments, microorganisms generally have very rapid rates of generation, mutation and natural selection, which allow very fast adaptation and extraordinary biodiversity to develop. An approximate estimate of the total microbial population in soil near the ground surface is of the order of $10^{9}-10^{12} / \mathrm{kg}$ soil (Mitchell and Santamarina, 2005). However, the actual population may vary widely, depending on soil type and depth (Barns and NierzwickiBauer, 1997), since different types of bacteria live in different environments. Aerobic bacteria live in the presence of free or dissolved oxygen; anaerobic bacteria live in the absence of oxygen; and facultative bacteria can live with or without oxygen (Mitchell and Santamarina, 2005). Therefore, most microorgan- isms in subsurface environments are typically anaerobic or facultative bacteria, with the latter able to resort to fermentation in order to sustain their metabolism under anaerobic conditions.

Peat in natural ecosystems is categorised as acrotelm or catotelm. These can be distinguished by seasonal groundwater level and degree of humification. Most microorganisms in the acrotelm are aerobic since this layer obtains sufficient oxygen from the atmosphere, from precipitation and by virtue of periodic/seasonal fluctuations of the groundwater table (Hobbs, 1986). The conditions in the underlying catotelm are generally anaerobic, in which microorganisms are specialised in character and also less populous (Farrell, 2012; Hobbs, 1986). Anthropogenic activity in mire can have a significant effect on the microorganism population, with bacterial populations decreasing from natural sites, to restored sites, to harvested sites (Glatzel et al., 2004). Low microorganism counts in harvested peat are generally attributed to the reduction in carbon substrates and nutrients as well as the non-conducive environment.

Bacteria such as Firmicutes and Bacteroidetes, which are key players for degradation of biopolymers in various habitats, only exist in small populations in mire, with typical bacterial counts of $\sim 2.6 \times 10^{5} \mathrm{CFU} / \mathrm{g}$ dry peat (Hunter et al., 2006), where CFU is colony-forming unit, a measure of the microorganism population present. Cellulose substrates may be degraded by Acidobacteria or Cytophaga-like bacteria, which possess cellulolytic potential and are commonly found in peat (Pankratov et al., 2011). However, the growth of Acidobacteria is relatively slow and is not stimulated by the addition of nitrogen, unlike Cytophaga which are responsive to environmental changes. Hence, the authors suspect that Cytophaga-like bacteria play a key role in accelerating the decomposition rate in peat once the main limiting factors have been altered optimally. Fungi are also active in the acrotelm, with mean fungal counts of $\sim 3.7 \times 10^{6} \mathrm{CFU} / \mathrm{g}$ dry peat (Hunter et al., 2006), although their growth rate declines with depth on account of increasingly anaerobic and saturated conditions. Fungi possess versatile hydrolytic capabilities and are capable of degrading cellulose, soluble phenolics, pectin, starch, chitin and other biopolymers (Pankratov et al., 2011).

\section{Materials and methods}

\subsection{Peat material and selection of additives}

The peat material for the present study was obtained from below the natural groundwater table at Ballydermot raised bog, County Kildare, Ireland. The sampled material was stored in airtight containers before a suite of laboratory tests were performed on control specimens. The main decomposition-limiting factors of other peat specimens were adjusted within the optimum ranges of $\mathrm{pH} 7 \cdot 0-7 \cdot 5$ and $\mathrm{C}: \mathrm{N}=25: 1$ to $30: 1$ by the addition of PPFA (obtained from Lanesborough Power Station, County Longford, Ireland) and a commercial nitrogenous fertiliser, namely urea.

PPFA is a highly alkaline, granular material that has been used, 
for example, as a replacement for lime or kiln dust in alkaline stabilisation of municipal sewage sludge (O'Kelly, 2006b). Urea was also selected as an additive since it contains $\sim 46 \%$ nitrogen. Hence, the addition of a small amount of this material would produce a significant reduction in the $\mathrm{C}: \mathrm{N}$ ratio for peat. Both additives were supplied in granular form and were crushed using a pestle and mortar to ensure uniformity of mixing for the peat blends.

\subsection{Characterising the test materials}

Selected properties of the test materials, including C:N ratio of the natural peat, were determined in order to establish baseline readings for comparison with the different peat blends. Water content determinations were performed by oven-drying representative specimens at $105^{\circ} \mathrm{C}$ over a period of $48 \mathrm{~h}$. The liquid limit (LL) and plastic limit (PL) values were determined using the $80 \mathrm{~g}-30^{\circ}$ fall-cone LL apparatus and the Casagrande threadrolling method. The material for the LL test was prepared by first removing coarse fibres using tweezers (as allowed by the British Standard) and then mixing the remaining material using a broadbladed knife to produce a homogeneous paste. The specific gravity of solids was determined using the small pyknometer method, using kerosene instead of distilled water as the liquid in the pyknometer bottles. The loss-in-dry mass on ignition was determined by igniting specimens of the powdered oven-dried materials in a muffle furnace at $440^{\circ} \mathrm{C}$ over an $18 \mathrm{~h}$ period. The above tests were performed in accordance with BS 1377 (BSI, 1990a, 1990b). The peat fibres were separated by washing representative peat specimens on the $150 \mu \mathrm{m}$ sieve, with the fibre content (FC) determined by expressing the oven-dried mass of the retained material as a percentage of the specimen dry mass (ASTM, 2008). The level of decomposition of the peat was classified by determining its humification number $(\mathrm{H})$ between 1 and 10, where $\mathrm{H}_{1}$ refers to a peat that has undergone no decomposition and $\mathrm{H}_{10}$ is a completely decomposed peat. Although the term humification strictly means the content of humic substances in peat, it is generally taken to mean, in this context, the same thing as decomposition.

\subsection{Determination of required amount of additives}

The amounts of PPFA and urea required to achieve optimum $\mathrm{pH}$ and $\mathrm{C}: \mathrm{N}$ for the blended peat were determined in two stages, each involving a number of trial mixes. In the first stage, different amounts of PPFA $(27 \%, 55 \%, 109 \%$ and $160 \%$ of the peat dry mass) were added and mixed with the peat at its natural water content. The resulting $\mathrm{pH}$ values were measured using an electronic $\mathrm{pH}$ meter, thereby establishing a relationship between $\%$ PPFA and $\mathrm{pH}$, from which the precise amount of PPFA required to achieve optimum $\mathrm{pH}$ for the blended peat was determined. In the second stage, the $\mathrm{C}: \mathrm{N}$ ratio of different peat blends having a $\mathrm{pH}$ in the optimum range $7 \cdot 0-7 \cdot 5$ was determined by elemental analysis using an Elementar VARIO El cube instrument. Specimens were tested in triplicate for each test run. The amount of urea required to produce material with $\mathrm{C}: \mathrm{N}$ values in the optimum range 15-30:1 were determined from these data using the method of Barbarick (2006). Selected index tests were also performed on peat blends prepared for both of these stages.

\subsection{Structure and arrangement of peat fibres}

Optical images of the undisturbed and reconstituted peat were examined in order to assess the structure and arrangement of the peat fibres. Undisturbed specimens were obtained from the bog site using a $100 \mathrm{~mm}$ diameter by $1.0 \mathrm{~m}$ long thin-walled sampling tube. This tube had a sharp cutting edge to minimise disturbance caused by tearing of the fibres and compression of the core during sampling (O'Kelly, 2009). Remoulded material was prepared from undisturbed peat using a paddle mortar-mixer. Specimens $150 \mathrm{~mm}$ diameter by $150 \mathrm{~mm}$ long were formed from the remoulded material and compressed one-dimensionally over a 28-day period under an applied stress of $14 \mathrm{kPa}$, which had been established as the pre-consolidation pressure of the in situ peat. For imaging purposes, the specimens of undisturbed and reconstituted peat were allowed to air dry beforehand at ambient temperature, as suggested by Zainorabidin et al. (2010), in order that the constituent fibres could be more clearly observed.

\subsection{Evaluation of available microorganisms}

Assessments of the availability of microorganisms in natural peat and also of the effect of PPFA addition on existing microorganism populations present were performed in order to evaluate the potential for further decomposition. A standard plate-count technique, known as direct viable count, was used to enumerate the population of microorganisms in the peat. The technique involved transferring a known peat mass onto a semi-solid medium, spreading the dilution across the plate and counting the colonies that formed after specified incubation periods. In this experiment, precisely $1.0 \mathrm{~g}$ of material was randomly sampled from the wet peat and added to $9.0 \mathrm{ml}$ of sterile saline (i.e. $10^{-1}$ dilution). The mixture was agitated using an electric shaker to disperse the microorganisms contained in the peat mass. The suspension was diluted further to $10^{-2}, 10^{-3}$ and $10^{-4}$ by sequentially transferring $1.0 \mathrm{ml}$ of each suspension into $9.0 \mathrm{ml}$ of sterile saline. From each dilution $0.1 \mathrm{ml}$ was then plated in duplicate. Two types of semi-solid medium, namely tryptic soy agar tenfold-diluted (TSA 1/10) and peat agar, were used in these experiments to assess which medium was most suitable for cultivation. All plates were incubated both aerobically and anaerobically at a constant temperature of $20^{\circ} \mathrm{C}$. The population or concentration of microorganisms/cells in a sample was assessed by counting the number of CFUs formed on the plate after 5- and 10-day cultivation periods, with the result expressed as CFU/g dry peat on the plated sample. Note that this plate-count technique only detects up to about $5 \%$ of the total population of viable microorganisms present on account of the very controlled test conditions, in particular the specific nutrients supplied in the semi-solid media and set incubation temperature of $20^{\circ} \mathrm{C}$. Optimum growth would occur for other microorganism populations present in peat under different incubation environments. However, the experimental results sufficiently reflect the availability of microorganisms in the peat. 


\section{Results}

\subsection{Properties of peat and PPFA materials}

Selected properties of the natural peat and PPFA materials are presented in Table 1. It proved difficult to perform tests for LL, and particularly PL, on the peat due to its fibrous nature. The measured LL value was extremely high but consistent with the range typically reported for peats (Hobbs, 1986). Soil threads could not be rolled out to $3 \mathrm{~mm}$ in diameter, hence the natural peat was reported as non-plastic. Since the Atterberg limits of peat do not significantly correlate with its mechanical behaviour (Hobbs, 1986), it was decided not to repeat these particular tests for the different peat blends. The measured specific gravity of solids for the natural peat was 1.43 , in the range $1.4-1.5$ reported for cellulose and lignin (Hobbs, 1986), and consistent with its

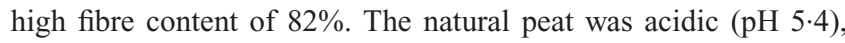
with total carbon and nitrogen contents of $54.2 \pm 1.3 \%$ and $1 \cdot 25 \pm 0.03 \%(n=3)$, respectively, giving a mean $\mathrm{C}: \mathrm{N}$ ratio of $\sim 43: 1$. The crushed PPFA material comprised 30\% silt and $70 \%$ sand (Figure 1) and was classified as well-graded very silty sand of high plasticity.

A visual inspection indicated that the peat was mainly composed

\begin{tabular}{lcc}
\hline \multirow{2}{*}{ Property } & \multicolumn{2}{c}{ Material } \\
\cline { 2 - 3 } & Peat & PPFA \\
\hline Water content: \% & 1330 & $18 \cdot 5$ \\
Liquid limit: \% & 790 & 60 \\
Plastic limit: \% & - & 51 \\
Specific gravity of solids & $1 \cdot 43$ & $2 \cdot 59$ \\
Loss in dry mass on ignition: \% & $98 \cdot 5$ & $4 \cdot 4$ \\
Fibre content: \% & 78 & 0 \\
pH & $5 \cdot 4$ & $11 \cdot 8$ \\
C:N ratio & $42 \cdot 8 \pm 0 \cdot 4: 1$ & 0
\end{tabular}

Table 1. Selected properties of test materials

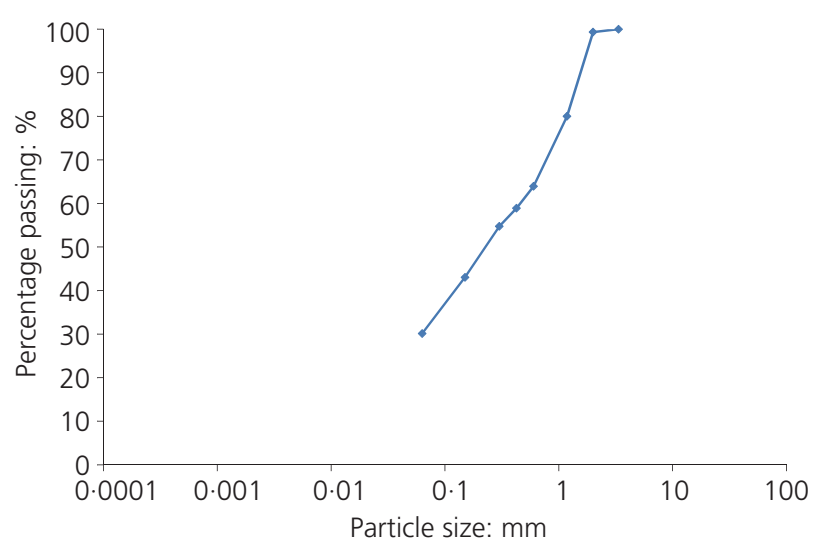

Figure 1. Grading curve for crushed PPFA material of moderately decomposed $\left(\mathrm{H}_{5-6}\right)$ Sphagnum mosses, which are the dominant plant species found in most raised bogs in temperate regions. The natural peat was categorised as fibric $78 \%$, low to medium ash, moderately acidic, Sphagnum-CarexCladium-Alnus-Betula-Phragmited peat (ASTM, 2007) and was classified as $\mathrm{SCWPh}-\mathrm{H}_{5-6}-\mathrm{B}_{4}-\mathrm{F}_{3}-\mathrm{R}_{2}-\mathrm{W}_{0}$ according to the modified von Post peat classification system (Landva and Pheeney, 1980).

\subsection{Structure and arrangement of peat fibres}

Figure 2 presents optical images of dried, natural peat specimens, which confirm that most of the plant matter present was already in a moderately decomposed condition. Peat fibres such as leaves and stems were still recognisable, although the difference between such elements was more obvious for undisturbed rather than reconstituted material. The structural arrangement of the fibres changed on remoulding, although it appeared random for both undisturbed and reconstituted materials, without showing any specific trend or direction.

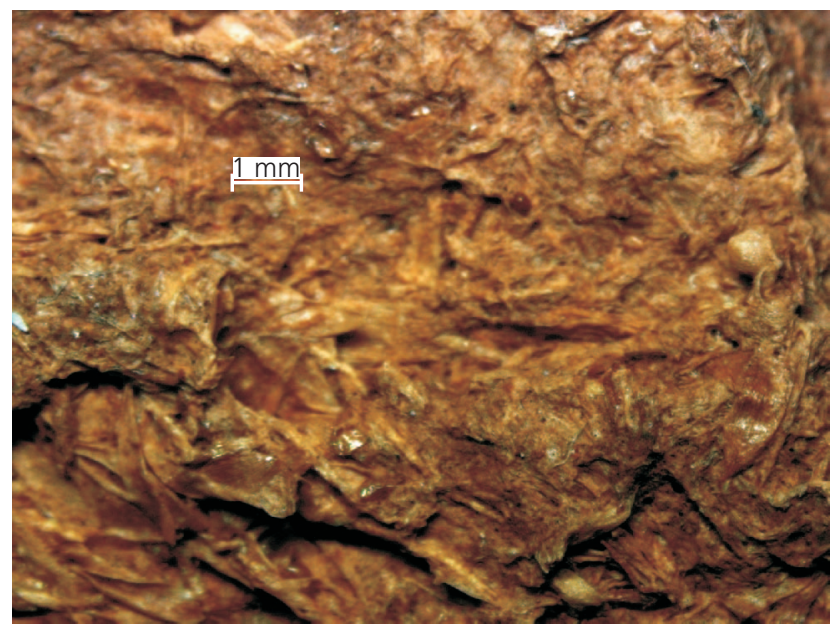

(a)

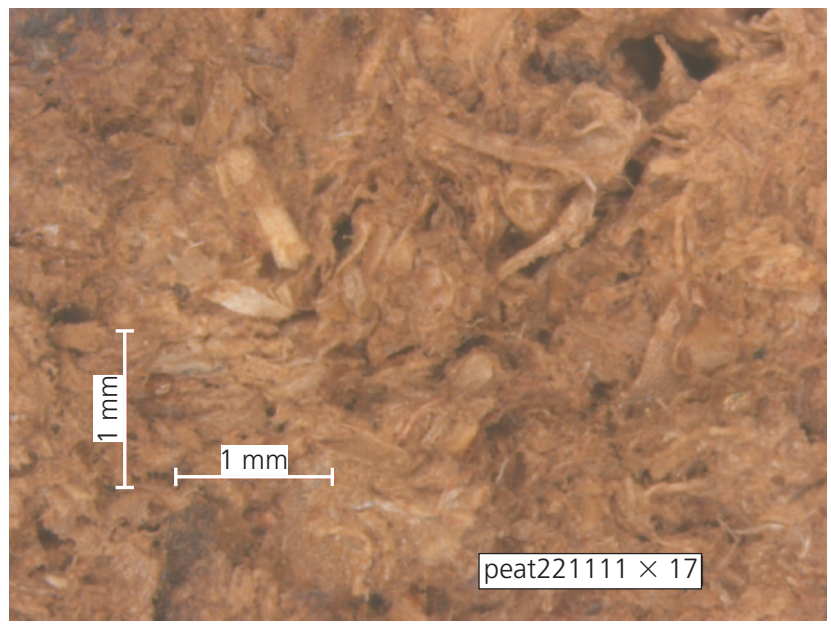

(b)

Figure 2. Optical images of natural peat: (a) undisturbed and (b) remoulded 


\subsection{Effectiveness of additives and mixing process}

The addition of PPFA material to the peat changed the soil properties (Figure 3), with significant reductions in water content and loss on ignition compared with increases in specific gravity of solids and $\mathrm{pH}$. However, the addition of urea in similar quantities did not appear to have a significant effect, apart from reducing the water content (Figure 3(c)).

Since PPFA itself is highly alkaline (pH 11.8), an increase in the proportion of this material increased the $\mathrm{pH}$ of the blended peat (Figure 3(a)), with the optimum range of $\mathrm{pH} 7 \cdot 0-7 \cdot 5$ achieved by adding $\sim 30 \%$ of PPFA, based on the peat dry mass (equivalent to $22.7 \%$ of the total dry mass of the peat blend). The addition of greater amounts of PPFA produced an alkaline blend, which would inhibit the growth of microorganisms and microbial activity.

Further investigations indicated that the $\mathrm{C}: \mathrm{N}$ ratio had increased slightly from originally $43 \cdot 4: 1$ for the natural peat to $51 \cdot 5: 1$ $(n=6)$ for the $30 \%$ PPFA-peat blend on account of additional carbon present in PPFA, which typically constituted $\sim 8 \%$ of its dry mass. Precisely $2 \cdot 2 \%$ of urea, again based on the peat dry mass (equivalent to $1.63 \%$ of the total dry mass of the peat

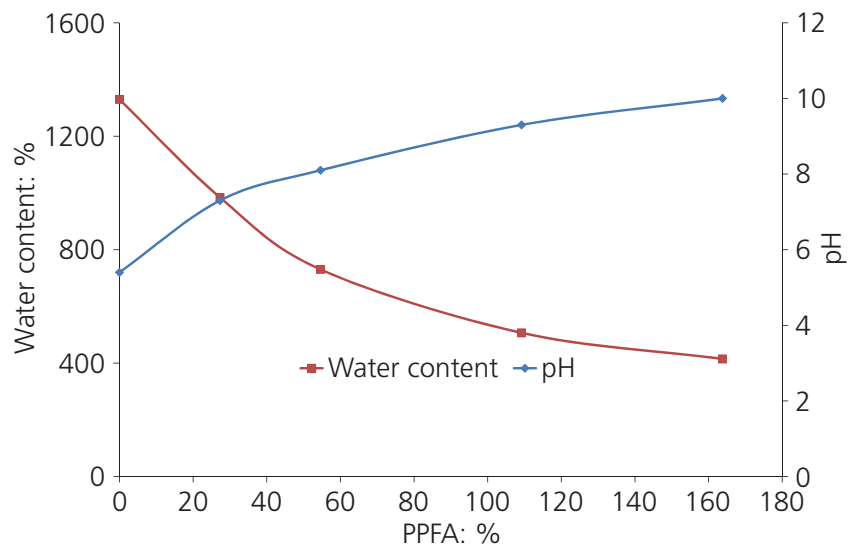

(a)

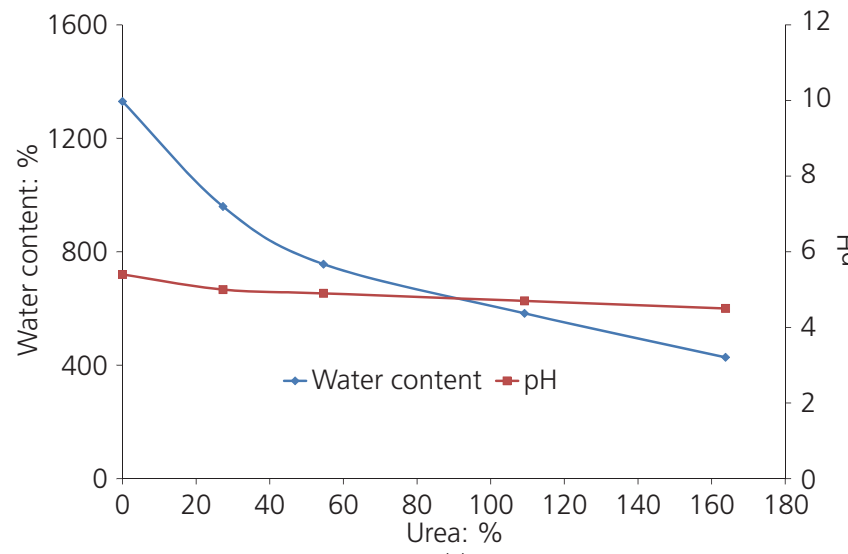

(c)

Figure 3. Effects of PPFA and urea addition on selected physical properties blend), was necessary in order to achieve the optimum C:N range of 25-30:1 for the blended peat (Table 2). The consistency of these data for the different blends confirms the effectiveness of these additives and of the methodology used in achieving the target ranges of $\mathrm{C}: \mathrm{N}$ and $\mathrm{pH}$.

\subsection{Availability of microorganisms}

Table 3 presents data of mean microorganism counts, expressed as $\mathrm{CFU} / \mathrm{g}$ dry peat, from plate-count tests performed on natural peat obtained from below the groundwater table. A significant and highly variable number of colonies formed on plates with TSA $1 / 10$ (Figure 4), indicating that it was a suitable medium for cultivation of existing microorganisms present in peat at the Ballydermot sampling site. However, no colonies were observed for plates with the peat agar medium. Similar findings were reported by Khammar et al. (2004). The mean microorganism counts measured for the natural peat are consistent with the value of $\sim 2.6 \times 10^{5} \mathrm{CFU} / \mathrm{g}$ dry peat reported by Hunter et al. (2006). Note that the peat test material had been randomly selected from the peat core. Hence, the large variation in the number of colonies formed on plates with TSA $1 / 10$ may be explained by the large variation in microorganism populations that naturally

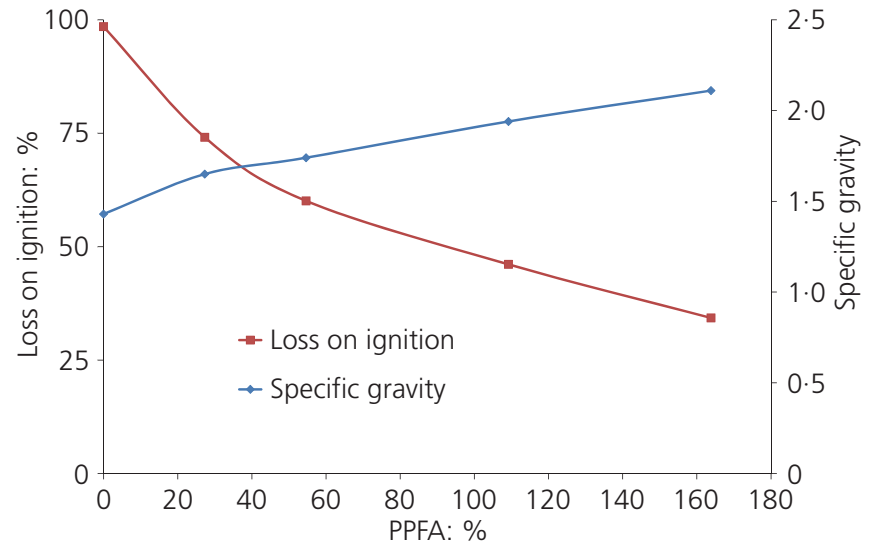

(b)

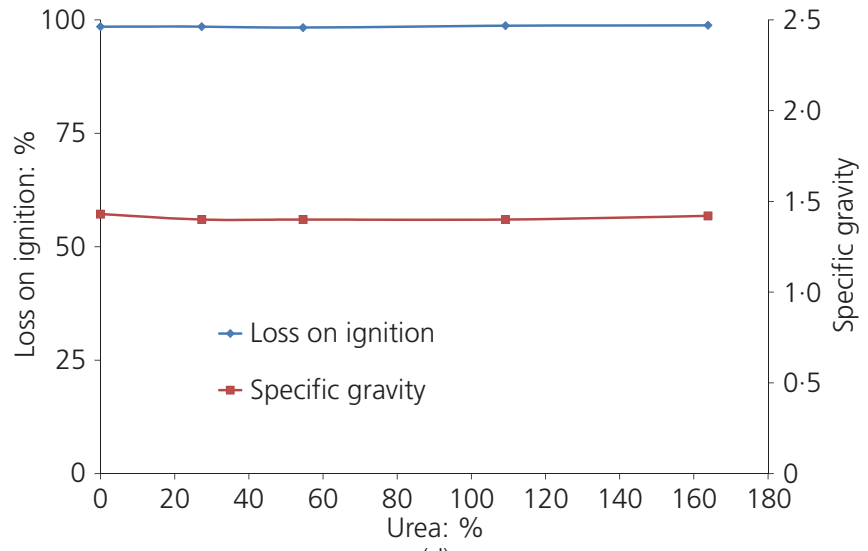

(d) 


\begin{tabular}{|c|c|c|c|c|c|c|c|}
\hline \multirow[t]{2}{*}{ Peat blends } & \multirow[t]{2}{*}{ Test run } & \multicolumn{6}{|c|}{ Property } \\
\hline & & $\begin{array}{c}\text { Water } \\
\text { content: \% }\end{array}$ & $\begin{array}{l}\text { Specific } \\
\text { gravity }\end{array}$ & $\begin{array}{c}\text { Loss on } \\
\text { ignition: \% }\end{array}$ & $\mathrm{pH}$ & $\begin{array}{c}\text { Total carbon } \\
\text { content: \% }\end{array}$ & $C: N$ \\
\hline \multirow[t]{3}{*}{$30 \%$ PPFA } & A & 951 & 1.62 & 73 & $7 \cdot 4$ & $38 \cdot 8 \pm 1 \cdot 0$ & $50 \cdot 1 \pm 2 \cdot 3$ \\
\hline & B & 892 & 1.60 & 70 & $7 \cdot 3$ & $38.9 \pm 0.6$ & $51.6 \pm 1.4$ \\
\hline & C & 948 & $1 \cdot 60$ & 69 & $7 \cdot 3$ & - & - \\
\hline \multirow[t]{3}{*}{$30 \%$ PPFA $+2 \cdot 2 \%$ urea } & $A$ & 963 & 1.59 & 76 & $7 \cdot 2$ & $41.6 \pm 0.5$ & $30 \cdot 8 \pm 0 \cdot 1$ \\
\hline & B & 936 & $1 \cdot 57$ & 75 & $7 \cdot 2$ & $41 \cdot 4 \pm 0.4$ & $30 \cdot 9 \pm 1 \cdot 2$ \\
\hline & C & 967 & $1 \cdot 60$ & 73 & $7 \cdot 3$ & $41 \cdot 3 \pm 1 \cdot 1$ & $29 \cdot 5 \pm 0 \cdot 4$ \\
\hline
\end{tabular}

Table 2. Selected properties and C:N ratio of 30\% PPFA-peat blends

\begin{tabular}{llcc}
\hline Sample & Incubation & \multicolumn{2}{c}{ Mean microorganism counts: CFU/g } \\
\cline { 3 - 4 } & & 5 days & 10 days \\
\hline A & Aerobic & $3.7 \times 10^{5}$ & $3.7 \times 10^{5}$ \\
& Anaerobic & - & $2.2 \times 10^{5}$ \\
B & Aerobic & $1.5 \times 10^{6}$ & $1.5 \times 10^{6}$ \\
& Anaerobic & - & $6.4 \times 10^{5}$
\end{tabular}

Table 3. Microorganism counts for natural peat plated with tryptic soy agar (1/10)

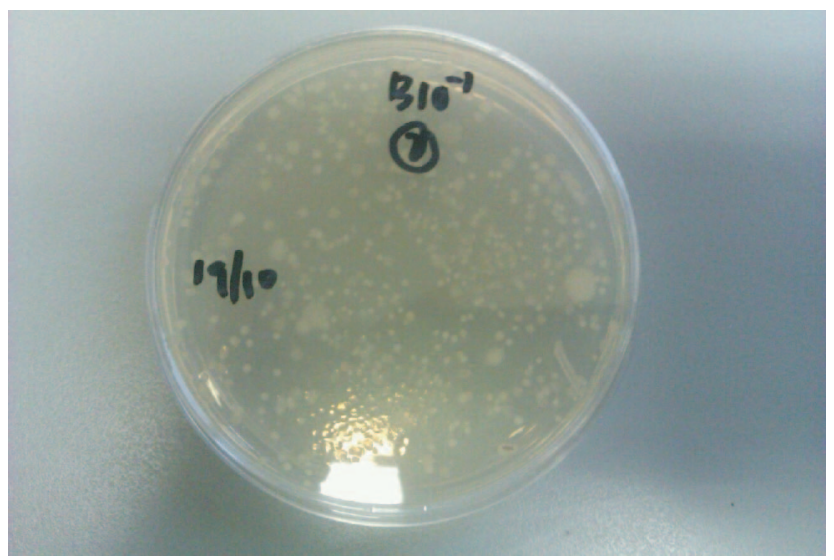

Figure 4. Colonies formed on a plate with tryptic soy agar

occurs with depth in mire (Barns and Nierzwicki-Bauer, 1997). Furthermore, the microorganisms in the peat were mostly facultative in character, although a greater population had formed under aerobic incubation, which was evidently more favourable for bacterial growth. Some of these microorganisms are expected to be key decomposers with cellulolytic potential (e.g. Firmicutes, Bacteroidetes, Acidobacteria, and Cytophaga) and also fungi capable of degrading celluloses in peat (Hunter et al., 2006; Pankratov et al., 2011). A further observation was that no significant increase in population occurred over the incubation period of between 5 and 10 days, presumably because the available nutrients on the plates had already been exhausted after the first 5 days. The determination of the type and species of microorganisms present in the peat was not possible using these techniques and was beyond the scope of this study, as was the rate of nutrient decrease in TSA $1 / 10$ medium, which could potentially be correlated with the rate of microbe growth.

The mean microorganism count for the optimum peat blend (i.e. addition of $30 \%$ PPFA plus $2.2 \%$ urea) was $\sim 9.4 \times 10^{5} \mathrm{CFU} / \mathrm{g}$ shortly after its preparation, from which it is concluded that these additives appear to have no adverse effect on the existing population of microorganisms in natural peat. This population would be expected to increase remarkably once the ambient temperature had been increased within the optimum range of 35$40^{\circ} \mathrm{C}$ for decomposition.

\section{Discussion}

\subsection{Potential environmental issues}

Negative environmental effects specifically arising from the addition of PPFA and urea to peat have not been reported in the literature, possibly on account of the limited use of these materials in geotechnical engineering work. The chemical components making up PPFA are similar to those in ordinary Portland cement (OPC) and coal pulverised fuel ash (PFA), albeit in different quantities (Table 4). Therefore, the potential environmental hazards arising from the application of PPFA in the field are expected to be similar to those relating to the application of coal PFA. Among possible concerns is the release of environmental contamination into the peat pore-water and ultimately into groundwater. The elements of concern are potentially leachable heavy metals in PPFA and the increase of their uptake by the surrounding environment. Nevertheless, as cations, the heavy metals have limited mobility in more alkaline soil environments neutralised by the addition of fly ash (Kumpiene et al., 2007). The chemical reaction of the added nitrogen (urea), enhanced by microbial activity, may also produce additional nitrate or ammo- 


\begin{tabular}{|c|c|c|c|c|c|c|}
\hline \multirow[t]{2}{*}{ Oxide } & \multicolumn{2}{|c|}{ OPC: \% } & \multicolumn{2}{|c|}{ Coal PFA: \% } & \multicolumn{2}{|c|}{ PPFA: \% } \\
\hline & Typical & Range & Typical & Range & Typical & Range \\
\hline $\mathrm{SiO}_{2}$ & $20 \cdot 0$ & $17 \cdot 0-25 \cdot 0$ & 48.0 & $45 \cdot 0-51 \cdot 0$ & $35 \cdot 1$ & $15 \cdot 5-65 \cdot 0$ \\
\hline $\mathrm{Al}_{2} \mathrm{O}_{3}$ & $6 \cdot 0$ & $3 \cdot 0-8 \cdot 0$ & $27 \cdot 0$ & $24 \cdot 0-32 \cdot 0$ & $5 \cdot 7$ & $3 \cdot 5-22 \cdot 5$ \\
\hline $\mathrm{Fe}_{2} \mathrm{O}_{3}$ & $3 \cdot 0$ & $0.5-0.6$ & 9.0 & $7 \cdot 0-11 \cdot 0$ & $3 \cdot 0$ & $2 \cdot 0-22 \cdot 5$ \\
\hline $\mathrm{CaO}$ & $63 \cdot 0$ & $60 \cdot 0-67 \cdot 0$ & $3 \cdot 3$ & $1 \cdot 1-5 \cdot 4$ & $22 \cdot 7$ & $9 \cdot 0-47 \cdot 0$ \\
\hline $\mathrm{MgO}$ & 1.5 & $0.5-4.0$ & $2 \cdot 0$ & $1 \cdot 5-4 \cdot 4$ & $5 \cdot 6$ & $3.4-9.8$ \\
\hline $\mathrm{K}_{2} \mathrm{O}$ & 0.5 & $0 \cdot 3-1 \cdot 2$ & $3 \cdot 8$ & $2 \cdot 8-4 \cdot 5$ & $0 \cdot 1$ & $0.03-0.2$ \\
\hline $\mathrm{Na}_{2} \mathrm{O}$ & 0.5 & $0 \cdot 3-1 \cdot 2$ & $1 \cdot 2$ & $0.9-1 \cdot 7$ & 0.4 & $0.1-0.7$ \\
\hline $\mathrm{SO}_{3}$ & $2 \cdot 0$ & $2 \cdot 0-3 \cdot 5$ & 0.6 & $0 \cdot 3-1 \cdot 3$ & $17 \cdot 5$ & $0.4-17 \cdot 5$ \\
\hline
\end{tabular}

Table 4. Typical chemical compositions of OPC and PFAs

nia in the peat environment, potentially resulting in eutrophication in the long term. However, in the context of the amount added ( $2 \cdot 2 \%$ urea by peat dry mass) and the natural release of ammonia from peat, the additional effects of nitrogen release are likely to be negligible. The potential increase in emission of greenhouse gases to the atmosphere as a result stimulated decomposition confined to the bearing peat stratum for pertinent engineering works may not be a major problem.

\section{Conclusions}

The premise of this study was that stimulated decomposition of fibrous peat deposits in advance of the main construction works may reduce secondary compression settlement, which often exceeds primary consolidation settlement in peat, thereby potentially reducing the total anticipated settlement of the bearing stratum over the design life by a significant amount. The experimental laboratory study has demonstrated that the main decomposition-limiting factors for fibrous peat of high $\mathrm{C}: \mathrm{N}$ ratio and high $\mathrm{pH}$ can be artificially adjusted within the optimum reported ranges of $25-30: 1$ and $7 \cdot 0-7 \cdot 5$, respectively, by the addition of sufficient amounts of basic and nitrogenous materials. PPFA was found to be an effective additive on account of its high alkalinity.

The optimum blend for the moderately decomposed Sphagnum peat considered in this study required the addition of 30\% PPFA plus $2 \cdot 2 \%$ urea (based on the peat dry mass), which is equivalent to $\sim 21 \mathrm{~kg}$ and $\sim 1.5 \mathrm{~kg}$, respectively, per cubic metre of wet peat. These amounts of additives are reasonable and manageable for practical use with the latest in situ mixing and treatment techniques. PPFA material, which is presently considered as a waste stream, could be sourced locally in PPFA-producing countries and beneficially incorporated in these ground-improvement works. This approach may prove to be more sustainable than conventional ground improvement or excavate-and-replace techniques currently used for construction works on such soft deposits. However, the application of these experimental findings in the field may not be straightforward and will require further studies in the field. Furthermore, the optimum blend deduced from this study may not be directly applicable to other types of fibrous peat on account of differences in botanical composition and/or in the values of the decomposition-limiting factors, which depend on the climatic region and peat formation process.

\section{Acknowledgements}

The authors acknowledge contributions to the research work from the following Trinity College Dublin personnel: Martin Carney and Eoin Dunne, Department of Civil, Structural and Environmental Engineering (DCSEE) in obtaining the test-materials and performing the geotechnical laboratory tests; Paul Johnston, DCSEE, for advice on environmental issues; Dr Ronald Russell and Connie Crowley-Cribbin, Department of Microbiology, for advice and assistance with the microbiology work; Mark Kavanagh, Centre for the Environment, in performing tests for $\mathrm{C}: \mathrm{N}$ determination; and Derek Simpson, Centre for Microscopy and Analysis, for assistance with the optical images work. The first author gratefully acknowledges a research scholarship from the Public Service Department of Malaysia.

\section{REFERENCES}

ASTM (2007) D4427-07: Standard classification of peat samples by laboratory testing. ASTM International, West Conshohocken, PA, USA.

ASTM (2008) D1997-91: Standard test method for laboratory determination of the fiber content of peat samples by dry mass. ASTM International, West Conshohocken, PA, USA.

Barbarick KA (2006) Organic Materials as Nitrogen Fertilizers. Crop Series No. 0·546. Colorado State University, Fort Collins, CO, USA.

Barns SM and Nierzwicki-Bauer SA (1997) Microbial diversity in modern subsurface, ocean, surface environment. In Geomicrobiology: Interactions Between Microbes and Minerals (Banfield JF and Nelson KH (eds)). Mineralogical Society of America, Washington, DC, USA, Ch. 2, pp. 35-71. Beuving J and van den Akker JJH (1996) Maaiveldsdaling van veengrasland bij twee polderpeilen in de polder Zegvelderbroek; vijfentwintig jaar zakkingsmetingen op het ROC Zegveld. SC-DLO, Wageningen, the Netherlands, SC-DLO Rapport 377. 
Blackford JJ and Chambers FM (1993) Determining the degree of peat decomposition for peat based palaeoclimatic studies. International Peat Journal 5: 7-24.

BSI (1990a) BS 1377-2:1990. Methods of test for soils for civil engineering purposes (classification tests). BSI, London, UK.

BSI (1990b) BS 1377-3:1990. Methods of test for soils for civil engineering purposes (chemical and electro-chemical tests). BSI, London, UK.

Drexler JZ, de Fontaine CS and Deverel SJ (2009) The legacy of wetland drainage on the remaining peat in the Sacramento-San Joaquin Delta, California, USA. Wetlands 29(1): 372-386.

Farrell ER (2012) Organics/peat soils. In ICE Manual of Geotechnical Engineering. Volume 1: Geotechnical Engineering Principles. Problematic Soils and Site Investigation (Burland J, Chapman T, Skinner HD and Brown M (eds)). Thomas Telford, London, UK, pp. 463-479.

Franzen LG (2006) Increased decomposition of subsurface peat in Swedish raised bogs: are temperate peatlands still net sinks of carbon? Mire and Peat 1 (Article 03): 1-16.

Glatzel S, Basiliko N and Moore T (2004) Carbon dioxide and methane production potentials of peats from natural, harvested and restored sites, Eastern Quebec, Canada. Wetlands 24(2): 261-267.

Hingley M (1993) Microscopic Life in Sphagnum. Richmond Publishing, Slough, UK.

Hobbs NB (1986) Mire morphology and the properties and behaviour of some British and foreign peats. Quarterly Journal of Engineering Geology 19(1): 7-80.

Hunter PJ, Petch GM, Calvo-Bado LA et al. (2006) Differences in microbial activity and microbial populations of peat associated with suppression of damping-off disease caused by Phythium sylvaticum. Applied and Environmental Microbiology 72(10): 6452-6460.

Khammar N, Malhautier L, Degrange V, Lensi R and Fanlo JL (2004) Evaluation of dispersion methods for enumeration of microorganisms from peat and activated carbon biofilters treating volatile organic compounds. Chemosphere 54(3): $243-254$

Kumpiene J, Lagerkvist A and Maurice C (2007) Stabilization of $\mathrm{Pb}$ - and $\mathrm{Cu}$-contaminated soil using coal fly ash and peat. Environmental Pollution 145(1): 365-373.

Landva AO and Pheeney PE (1980) Peat fabric and structure. Canadian Geotechnical Journal 17(3): 416-435.

Landva OA, Korpijaako EO and Pheeney PE (1983) Geotechnical classification of peats and organic soils. In Testing of Peats and Organic Soils, ASTM STP 820 (Jarrett PM (ed.)). ASTM International, West Conshohocken, PA, USA, pp. 37-51.

Matthiesen H (2004) State of Preservation and Possible Settling of Cultural Layers Below Bredsgarden and Bugaden Tenements, Bryggen, Bergen. Department of Conservation, National Museum of Denmark, Copehnhagen, Denmark, Report No. 10832-0004-3.

Mesri G and Ajlouni MA (2007) Engineering properties of fibrous peat. ASCE Journal of Geotechnical and Geoenvironmental Engineering 133(7): 850-866.
Mitchell JK and Santamarina JC (2005) Biological considerations in geotechnical engineering. ASCE Journal of Geotechnical and Geoenvironmental Engineering 131(10): 1222-1233.

O'Kelly BC (2006a) Compression and consolidation anisotropy of some soft soils. Geotechnical and Geological Engineering 24(6): $1715-1728$

O'Kelly BC (2006b) Geotechnical properties of municipal sewage sludge. Geotechnical and Geological Engineering 24(4): $833-850$

O'Kelly BC (2008) Effect of biodegradation on the consolidation properties of a dewatered municipal sewage sludge. Waste Management 28(8): 1395-1405.

O'Kelly BC (2009) Development of a large consolidometer apparatus for testing peat and other highly organic soils. SUO-Mires and Peat 60(1/2): 23-36.

O'Kelly BC (2013) Characterisation and undrained shear strength of amorphous clay. Proceedings of the Institution of Civil Engineers - Geotechnical Engineering, http://dx.doi.org/ 10.1680/geng.11.00025.

Pankratov TA, Ivanova AO, Dedysh SN and Liesack W (2011) Bacterial populations and environmental factors controlling cellulose degradation in an acidic Sphagnum peat. Environmental Microbiology 13(7): 1800-1814.

Pichan SP and O'Kelly BC (2012) Effect of decomposition on the compressibility of fibrous peat. Proceedings of the ASCE Geo-Congress 2012: State of the Art and Practice in Geotechnical Engineering, San Francisco, CA, USA, pp. 4329-4338.

Price JS, Cagampan J and Kellner E (2005) Assessment of peat compressibility: is there an easy way? Hydrological Processes 19(17): 3469-3475.

Wardwell RE, Charlie WA and Doxtader KA (1983) Test method for determining the potential for decomposition in organic soils. In Testing of Peats and Organic Soils, ASTM STP 820 (Jarrett PM (ed.)). ASTM International, West Conshohocken, PA, USA, pp. 218-229.

Zainorabidin A, Wijeyesekera DC and Jayaratne R (2010) Fabric of peat soils using image analysis Proceedings of the 5 th Annual Conference on Advances in Computing and Technology, University of East London, London, UK, 38-44.

\section{WHAT DO YOU THINK?}

To discuss this paper, please email up to 500 words to the editor at journals@ice.org.uk. Your contribution will be forwarded to the author(s) for a reply and, if considered appropriate by the editorial panel, will be published as a discussion in a future issue of the journal.

Proceedings journals rely entirely on contributions sent in by civil engineering professionals, academics and students. Papers should be 2000-5000 words long (briefing papers should be 1000-2000 words long), with adequate illustrations and references. You can submit your paper online via www.icevirtuallibrary.com/content/journals, where you will also find detailed author guidelines. 